\title{
Revista Brasileira de
} Fruticultura

\section{Effect of industrial processing for obtaining guava paste on the antioxidant compounds of guava (Psidium guajava l.) 'Paluma' cv.}

\author{
Ana Paula Wolf Tasca Del'Arco $\&$ Célia Maria de Sylos ${ }^{2}$
}

\begin{abstract}
Some foods constituents are subject to change during thermal and/or industrial processing. In the fruit processing industry, guava pulp is used during guava off season to obtain guava paste, produced with the addition of sugar and citric acid, subjected to various thermal processes. This study evaluated the effect of industrial processing to obtain guava paste on the content of ascorbic acid, total carotenoids, total phenolic and total flavonoid present in guava 'Paluma' $\mathrm{cv}$. The results showed that there was an increase of antioxidants in guava pulp (15\% ascorbic acid, 59\% total carotenoids, $8 \%$ total phenolics and $54.5 \%$ total flavonoids), probably due to their increased concentration as a result of water loss during processing. There was a reduction in the contents of antioxidants compounds in guava paste $(42,13,31$ and $6.5 \%$ respectively). The antioxidant capacity was evaluated by the DPPH method, and the results showed that guava 'Paluma' cv. and its byproducts have an important antioxidant capacity, with moderate positive correlation among guava anti-radical DPPH • activity with the contents of acid ascorbic, carotenoids and phenolics and, for the guava paste anti-radical DPPH $\bullet$ activity, there was very high positive correlation with the content of carotenoids and high positive correlation with total content of phenolic compounds. Index terms: Ascorbic Acid, Carotenoids; Phenolics, Antioxidant Activity.

\section{Efeito do processamento industrial para obtenção de goiabada sobre os compostos antioxidantes da goiaba (Psidium guajava l.) da cv. 'Paluma'}

Corresponding author: apwt.delarco@gmail.com

Received: December 03, 2016. Accepted :June 14, 2017.

Copyright: All the contents of this journal, except where otherwise noted, is licensed under a Creative Commons Attribution License.

\section{$(\mathrm{cc}) \mathrm{EY}$}

Resumo- Alguns constituintes presentes nos alimentos podem sofrer mudanças durante o processamento térmico e/ou industrial. Na indústria de processamento de frutas, a polpa de goiaba é utilizada durante a entressafra da goiaba para a obtenção de goiabada, que por sua vez é produzida com adição de açúcar e ácido cítrico, submetida a diversos processos térmicos. Este trabalho avaliou o efeito do processamento industrial para a obtenção de goiabada sobre os teores de ácido ascórbico, carotenoides totais, fenólicos totais e flavonoides totais presentes na goiaba cv. 'Paluma'. Os resultados mostraram que houve aumento dos compostos antioxidantes na polpa de goiaba (15\% de ácido ascórbico, $59 \%$ de carotenoides totais, $8 \%$ de fenólicos totais e $54,5 \%$ de flavonoides totais), possivelmente pela concentração destes devido à perda de água no processo. Na goiabada, houve redução dos compostos antioxidantes ( $42 ; 13 ; 31$ e $6,5 \%$, respectivamente). A capacidade antioxidante da fruta, da polpa e da goiabada também foi avaliada, através do método DPPH, e os resultados mostraram que a goiaba cv. 'Paluma' e seus subprodutos têm importante capacidade antioxidante, havendo correlação positiva moderada entre a atividade antirradical $\mathrm{DPPH} \bullet$ da goiaba com o conteúdo de ácido ascórbico, carotenoides totais e fenólicos totais, e, para a atividade antirradical $\mathrm{DPPH} \bullet$ da goiabada, houve correlação positiva muito forte com os teores de carotenoides totais e correlação positiva forte com os teores de fenólicos totais.

Termos para indexação: Ácido Ascórbico, Carotenoides, Compostos Fenólicos, Capacidade Antioxidante.

${ }^{1}$ Nutritionist, Master in Food Science, Department of Food and Nutrition -Universidade Estadual Paulista "Julio de Mesquita Filho" - Câmpus Araraquara Araraquara - SP - E-mail: apwt.delarco@gmail.com. Part of the master's thesis of the first author. 


\section{Introduction}

Guava (Psidium guajava L.) is among Brazilian tropical fruits that stand out for its economic and nutritional importance (AMORIM et al., 2015; ARAÚJO et al., 2015; SEBRAE, 2016), and Brazil is among the world's top three fruit producers (TEIXEIRA et al., 2006; MENEZES et al., 2009). The fruit has been extensively studied and although it is an excellent source of exogenous nutrients and antioxidants, such as vitamin C, carotenoids, phenolic compounds and flavonoids (MELO et al., 2008; SOUSA et al., 2011a; 2011b; VIEIRA et al., 2011; FREIRE et al., 2012; 2013; ORDÓÑEZ-SANTOS et al., 2014; ARAÚJO et al., 2015; SILVA et al., 2016), the consumption of fresh guava is still low in the country, estimated at $300 \mathrm{~g}$ / inhabitant / year (SEBRAE, 2016). On the other hand, guava byproducts are quite consumed, and about $70 \%$ of guava production aimed at industrial processing is of 'Paluma' cultivar (AMORIM et al., 2015). Guava sweet, known as guava paste, is a traditional sweet and much appreciated by Brazilians, widely consumed by the lower purchasing power population (TEIXEIRA et al., 2006; MENEZES et al., 2009), being part of the basic diet in certain regions of the country.

In Brazil, it is estimated that about $53 \%$ of all fruit production is destined for processing (ARAÚJO et al., 2014). Guava is a climacteric fruit, and its harvest is concentrated in the period from January to April, showing a decline throughout the year, and guava pulp is a byproduct used by the industry during guava off-season (SEBRAE, 2016). Guava paste is a sweet obtained by the addition of sugar, citric acid (to adjust $\mathrm{pH}$ ) and pectin to guava pulp (ranging from 0.5 to $1.5 \%$ ), in addition to several concentration steps up to the final product in the desired consistency (TEIXEIRA et al., 2006; MENEZES et al., 2009). The steps involved in the processing of guava pulp and guava paste can promote changes in the fruit constituents, among them antioxidant compounds. In addition, in the fresh fruit, these bioactive compounds can have their amounts and concentrations altered according to the variety, maturation degree and the climatic and fruit cultivation conditions (MELO et al., 2008; DUZZIONI et al., 2010; ARAÚJO et al., 2015).

The antioxidant capacity of guava has been gaining prominence (ORDÓÑEZ-SANTOS and VÁZQUEZRIASCOS, 2010; FU et al., 2011; 2016; SOUSA et al., 2011a; 2011b; VIEIRA et al., 2011; ORDÓÑEZ-SANTOS et al., 2014; ARAÚJO et al., 2015; SILVA et al., 2016; ZAHIN et al., 2016). The method of reducing the DPPH radical (1,1-diphenyl-2-picryl-hydrazyl), monitored by decreasing the absorbance at a given wavelength, is one of the most widely used methods for determining the antioxidant capacity of an extract (BRAND-WILLIAMS et al., 1995; AMIN e MUKHRIZAH, 2006; MELO et al., 2008; DUZZIONI et al., 2010; SOUSA et al., 2011a; 2011b; VIEIRA et al., 2011; HERNÁNDEZ-ACOSTA et al., 2011; ARAÚJO et al., 2015).
The identification of the composition of antioxidant substances in foods, as well as the verification of possible changes or degradations that may occur during processing and storage due to the interference of factors such as temperature, light, $\mathrm{pH}$, relative humidity, gas composition and enzymatic system is of utmost importance (RODRIGUEZ-AMAYA, 1999; TEIXEIRA et al., 2006; ORDÓÑEZ-SANTOS and VÁZQUEZ-RIASCOS, 2010; FREIRE et al., 2013; ORDÓÑEZ-SANTOS et al., 2013; SILVA et al., 2016). This work is a comparative study with three observational conditions, defined as the stages of industrial processing (fresh fruit, guava pulp and guava paste), with the objective of evaluating the effect of industrial processing on the production of guava by-products 'Paluma' cv., such as guava pulp and guava paste, on the contents of ascorbic acid, total carotenoids, total phenolics and total flavonoids, as well as on the antioxidant capacity of the fruit and by-products.

\section{Material and Methods}

\section{Material}

Guava 'Paluma' cv., guava pulp and guava paste samples were supplied by Alimentos Predilecta LTDA, in the city of Matão (SP). Samples were collected from four batches of different production dates (blocking), with subsamples collected within the same lot to minimize internal variation, randomly performed to minimize bias, and analyses were performed with 3 replicates. The process of obtaining guava pulp consisted in fruit selection and grinding and enzymatic inactivation $\left(90^{\circ} \mathrm{C}\right.$ for 6 minutes); and for obtaining of guava paste, sugar, pectin and citric acid were added to guava pulp, with applications of different temperatures: $70^{\circ} \mathrm{C}$ for 35 minutes in the mixer; $70-75^{\circ} \mathrm{C}$ for 35 minutes for concentration; caramelization at $100^{\circ} \mathrm{C}$ for 15 minutes; and $80^{\circ} \mathrm{C}$ for 15 minutes in two subsequent concentration steps until reaching total soluble solids content around $70-75^{\circ}$ Brix.

\section{Preparation of samples}

Guava 'Paluma' cv. fruits were liquefied with peel and seeds, homogenized, packaged in amber bottles, sterilized and frozen at $-18^{\circ} \mathrm{C}$. Guava pulp samples were transferred from industrial bags to sterilized, amber bottles and frozen in freezer at $-18^{\circ} \mathrm{C}$. The guava paste was cut into cubes, packed in foil paper and then frozen $\left(-18^{\circ} \mathrm{C}\right)$. 


\section{Methods}

Ascorbic acid. The ascorbic acid content was determined by titulometry with 2,6-dichlorophenolindofenol, according to methodology described by Helrich (1990).

Total Carotenoids. Extraction was performed according to Pinto (2006). Carotenoids were extracted from 5 grams ( $\mathrm{g}$ ) of sample with methanol: ethyl ether (1:1), under vortex for 2 minutes and centrifuged for the same time at $6500 \mathrm{rpm}$; the process was repeated until the residue became colorless. Extracts were collected in a separator funnel with petroleum ether and ethyl ether and the methanol removed by successive washes with distilled water. The content of total carotenoids was determined by spectrophotometry with reading of the ethereal extract absorbance at $470 \mathrm{~nm}$ in a Beckman DU640 spectrophotometer. The lycopene extinction coefficient $\left(\mathrm{E}^{1 \%}{ }_{1 \mathrm{~cm}}=3450\right.$ in petroleum ether) was used to perform calculations (RODRIGUEZ-AMAYA, 1999).

Total phenolics. The total phenolic content was determined by the Folin-Ciocalteu colorimetric method (SCALBERT et al., 1989; TOOR and SAVAGE, 2006). Extraction was carried out with $10 \mathrm{~mL}$ of $70 \%$ acetone (YU and DAHEGREN, 2000), the mass used in the extraction of guava pulp and guava was $0.15 \mathrm{~g}$ and the guava paste was $0.25 \mathrm{~g}$. Samples were mixed to the extracting solvent for 1 minute in vortex, kept in the dark for 60 minutes at room temperature and then centrifuged at $6500 \mathrm{rpm}$ for 2 minutes. At controlled temperature $\left(50{ }^{\circ} \mathrm{C}\right.$ in a water bath), $0.5 \mathrm{~mL}$ of sample extracts were added of $2.5 \mathrm{~mL}$ of $0.2 \mathrm{~N}$ Folin-Ciocalteu reagent (1:10) and after 5 minutes $2 \mathrm{~mL}$ of sodium carbonate $(75 \mathrm{~g} / \mathrm{l})$ and after 5 minutes, samples were cooled and the absorbance reading was performed at $760 \mathrm{~nm}$ in a Beckman DU640 spectrophotometer. The analytical curve was constructed with gallic acid monohydrate standard $(100 \mu \mathrm{g} / \mathrm{mL}$ water $)$ at concentrations of $5,10,20,30$ and $40 \mu \mathrm{g} / \mathrm{mL}$. The results were expressed in gallic acid equivalent.

Total Flavonoids. Extraction was performed in the same manner as for total phenolics, with $70 \%$ acetone (YU and DAHEGREN, 2000), the mass used in the guava extraction was $2.5 \mathrm{~g}$, guava pulp was $2.9 \mathrm{~g}$ and the guava paste was $3.0 \mathrm{~g}$. The determination of the total flavonoid content was based on methodology described by Zhishen et al. (1999). To $5 \mathrm{~mL}$ of sample extracts, $0.3 \mathrm{~mL}$ of $5 \%$ sodium nitrite $(\mathrm{w} / \mathrm{v})(\mathrm{t}=0)$ were added. After 5 minutes, $0.6 \mathrm{~mL}$ of $10 \%$ aluminum chloride $(\mathrm{w} / \mathrm{v})$ were added. The reaction was stopped $(\mathrm{t}=11$ minutes) with the addition of $2 \mathrm{~mL}$ of $1 \mathrm{~N}$ sodium hydroxide and $2.1 \mathrm{~mL}$ of water. Samples were filtered on Whatman filter paper \# 01 and the absorbance reading was performed at $510 \mathrm{~nm}$ on a Beckman DU640 spectrophotometer. For the construction of the analytical curve, rutin standard $(1000 \mu \mathrm{g} / \mathrm{mL})$ at concentrations of $100,200,300,400$ and $500 \mu \mathrm{g} / \mathrm{mL}$ was used. The results were expressed in rutin equivalent.

Antioxidant capacity (antiradical DPPH• activity). The antiradical DPPH• activity was measured by the reduction of the DPPH (1,1-diphenyl-2-picrylhydrazyl) radical (BRAND-WILLIAMS et al., 1995). For extraction, $6 \mathrm{~mL}$ of ethanol were mixed in the samples for 2 minutes in vortex and centrifuged at $6500 \mathrm{rpm}$ for 5 minutes (VICENTE et al., 2006). For the reaction, $1575 \mu \mathrm{l}$ of DPPH solution $(100 \mu \mathrm{M}$ in methanol) were added to $1000 \mu$ l of sample extracts, kept in the dark at room temperature for 30 minutes. The absorbance reading was taken at $515 \mathrm{~nm}$ in Beckman DU640 spectrophotometer, immediately after mixing $(\mathrm{t}=0)$ and after the reaction $(\mathrm{t}$ $=30$ minutes). The results were expressed as $\%$ remaining $\mathrm{DPPH}$, calculated according to the equation:

$$
\% \mathrm{DPPH}_{\mathrm{rem}}=100 \mathrm{x}[\mathrm{DPPH}]_{\mathrm{rem}} /[\mathrm{DPPH}]_{\mathrm{t}=\mathrm{o}}
$$

Statistical analysis. Analysis of variance (ANOVA with significance level of 5\%) was used and the comparison of means was performed by the Tukey's test ( $\mathrm{p}<0.05$ ). The correlation between antioxidant compounds and the antioxidant capacity was established through the Pearson's correlation coefficient.

\section{Results and discussion}

\section{Ascorbic acid}

In the present work, the ascorbic acid behavior was similar for all batches, indicating an increase in ascorbic acid content in guava pulp and decrease in guava paste in relation to fresh guava. The ascorbic acid content increased by $14.82 \%$ in guava pulp and decreased by $41.94 \%$ in guava paste compared to the fresh fruit (Table 1). In the process of obtaining guava pulp, there is water loss, with concentration of compounds. Subsequently, the process of obtaining guava paste uses more severe temperatures, with loss / degradation of ascorbic acid, which corroborates results found in literature (JAWAHEER et al., 2003; TEIXEIRA et al., 2006; FREIRE et al., 2013; ORDÓÑEZSANTOS et al., 2013; SILVA et al., 2016), where more severe heat treatment of by-products causes degradation of ascorbic acid present in fresh fruit. Evaluating the effect of the thermal process, Jawaheer et al. (2003) found that guava processing resulted in the retention of $37.5 \%$ ascorbic acid in jelly and $79.6 \%$ in juice, since the production of jelly involves a more severe heat treatment than that of juice. 
Ascorbic acid is very sensitive and may suffer degradation during the processing and storage of products and by-products containing it (TEIXEIRA et al., 2006; FREIRE et al., 2013; ORDÓÑEZ-SANTOS et al., 2013; SILVA et al. al., 2016). According to Freire et al. (2013), there was a nearly $70 \%$ reduction in ascorbic acid content for frozen guava pulp $\left(-18^{\circ} \mathrm{C}\right.$ for 3 months), when compared to the fresh fruit. In another study, Freire et al. (2012) determined the vitamin C content in guava pulp flour from 3 different cultivars and verified a variation coefficient of $21.95 \%$ among them.

Studying the effect of storage (270 days in 3 different conditions) on the degradation of ascorbic acid in guava paste, Teixeira et al. (2006) verified that there was degradation of ascorbic acid in the matrix and that storage at low temperatures is the method that most preserves the nutrient. Guava paste stored at $5{ }^{\circ} \mathrm{C}$ showed almost $69 \%$ ascorbic acid retention, whereas guava paste stored at $30{ }^{\circ} \mathrm{C}$ without exposure to light showed retention rate of about $57 \%$ and the condition that most contributed to ascorbic acid degradation was that in which guava paste was kept at $30{ }^{\circ} \mathrm{C}$ with light exposure (46.0\% retention) (TEIXEIRA et al., 2006).

\section{Total Carotenoids}

Total carotenoid contents presented significant differences $(\mathrm{p}<0.05)$ among products, with an increase in total carotenoid content in the guava pulp of $58.65 \%$ and a decrease of $13.20 \%$ in the guava paste, both in relation to fresh fruit (Table 1).

The concentration of total carotenoids in guava 'Paluma' cv. was very expressive in this work $(7.88 \pm 1.48$ $\mathrm{mg}$ lycopene/100 g) and even guava residues presented as excellent sources of total carotenoids $(4.20 \pm 2.33 \mathrm{mg}$ of lycopene $/ 100 \mathrm{~g}$ ), increasing the interest in the use of these residues as functional ingredients in other industrial activities (ARAÚJO et al., 2014; SEO et al., 2014).

Carotenoids provide color to foods and have important organic functions (RODRIGUEZ-AMAYA, 1999). Guava pulp 'Paluma' cv. presents a pink coloration, which may be due to its carotenoid content, which is higher than the levels presented by guavas of white pulp. In a study to determine the chemical composition and identification of phenolic compounds of seven guava cultivars, Flores et al. (2015) verified that red pulp guava ('Thai Maroon'), followed by pink pulp guava ('Barbie Rosa', 'Homestead', 'Sardina 1' and 'Sardina 2'), showed antiradical DPPH activity greater than that of white pulp guavas ('Yen 2' and 'Sayla') (FLORES et al., 2015), which suggests that the total carotenoid content influences the antioxidant capacity of a fruit.

The total carotenoid content of a matrix can be affected by thermal processing (high temperatures for a short period of time); however, only initially, and there may be a reduction in total carotenoid content at the beginning of the thermal process, contributing to avoid the loss of this compound in longer thermal stages of the industrial process and during storage (RODRIGUEZ-AMAYA, 1999). If the heat treatment applied is severe, the cellular structure that protects the carotenoids can be destroyed, increasing the surface area, which could facilitate the oxidative degradation of carotenoids (initially isomerization and formation of epoxides and apocarotenoids) (RODRIGUEZ-AMAYA, 1999; ESCOBAR, 2006). The initial reduction of the total carotenoid content was also observed by Ordóñez-Santos and Vázquez-Riascos (2010), from guava pulp to obtain guava juice, with no subsequent losses of carotenoids during the storage period $\left(240\right.$ days at $\left.10{ }^{\circ} \mathrm{C}\right)$. In studies carried out with guava juice, it was observed that total carotenoid contents did not change in relation to storage and to the addition of different conservative agents (SILVA et al., 2016).

Escobar (2006) evaluated the effect of processing on lycopene and $\beta$-carotene contents in guava 'Paluma' cv. and verified that there was concentration of total carotenoid contents in the guava pulp in $114.4 \%$, which corroborates the findings of the present study. The author also verified that there was loss of $16.4 \%$ of total carotenoids in guava paste. The enzymatic inactivation in the processes of obtaining guava pulp and guava paste, plus the process of guava caramelization caused a decrease in the lycopene and $\beta$-carotene levels, and increase in the concentrations of cis isomer lycopene and cis isomer of $\beta$-carotene on a dry basis (ESCOBAR, 2006).

\section{Total Phenolics and Total Flavonoids}

In this work, the total phenolic and flavonoid contents had similar behavior among batches, with an increase in the contents of guava pulp (in comparison to the fresh fruit) and a decrease in guava paste (when compared to fresh guava) (Table 1). In relation to total phenolics, there was an increase of $8.27 \%$ in guava pulp and a decrease of $31.30 \%$ in guava paste; for total flavonoids, the increase in guava pulp was $54.56 \%$, and the decrease in guava paste was $6.50 \%$ (Table 1 ).

Different factors may influence the initial contents of phenolic compounds in fruits, such as extrinsic factors (climatic and planting conditions) and intrinsic factors (cultivar, variety and stage of fruit maturation) (MELO et al., 2008; ARAÚJO et al., 2015; FLORES et al., 2015). Freire et al. (2012) observed that in guava pulp flour, there was a variation of $4.5 \%$ in the content of phenolic compounds when comparing guava 'Século XXI', 'Paluma' and 'Pedro Sato' cultivars.

In fresh fruits, phenolic compounds are arranged in the structure of the vegetable, accumulated in the vacuoles as intermediary metabolites, being separated from oxidative enzymes. After the collapse of the cellular structures of the fresh fruit (by processing 
effect), temperature around $80{ }^{\circ} \mathrm{C}$ is able to increase the extractability and increase the number of free phenolic groups in the system due to the hydrolysis of glycosylated flavonoids, and also inactivation of oxidative enzymes, avoiding the loss of phenolic compounds that are released from cell walls (TOOR and SAVAGE, 2006; NUNES et al., 2016), which explains the findings of the present study, where there was an increase in the phenolic and flavonoid contents in the guava pulp. According to Nunes et al. (2016), drying temperatures for the production of guava powders increased the release of insoluble flavonoids, which allowed the presence of quercetin in the system.

Table 1 - Mean values ( \pm standard deviation) of ascorbic acid, total carotenoids, total phenolics and total flavonoids (variables) of guava cv. 'Paluma', guava pulp and guava paste, at different year times (four different batches).

\begin{tabular}{lccl|ccc}
\hline & \multicolumn{2}{c}{ Ascorbic Acid } & \multicolumn{2}{c}{ Total Carotenoids (mg lycopene/100g) } \\
\cline { 2 - 7 } & Guava & Pulp & Guava Paste & Guava & Pulp & Guava Paste \\
\hline Batches 1 & $63,38 \pm 0,01 \mathrm{aA}$ & $76,09 \pm 0,22 \mathrm{aB}$ & $31,48 \pm 0,46 \mathrm{aC}$ & $8,66 \pm 0,70 \mathrm{aA}$ & $11,53 \pm 1,68 \mathrm{aB}$ & $7,23 \pm 1,38 \mathrm{aC}$ \\
Batches 2 & $63,28 \pm 0,99 \mathrm{aA}$ & $80,48 \pm 0,47 \mathrm{bB}$ & $37,00 \pm 0,42 \mathrm{bC}$ & $8,57 \pm 1,52 \mathrm{aA}$ & $11,68 \pm 0,34 \mathrm{aB}$ & $5,81 \pm 0,24 \mathrm{bC}$ \\
Batches 3 & $52,36 \pm 0,47 \mathrm{bA}$ & $54,01 \pm 0,89 \mathrm{cA}$ & $29,91 \pm 0,67 \mathrm{aB}$ & $6,64 \pm 0,04 \mathrm{bA}$ & $12,92 \pm 1,10 \mathrm{bB}$ & $6,40 \pm 0,40 \mathrm{cA}$ \\
Batches 4 & $56,09 \pm 0,01 \mathrm{cA}$ & $59,37 \pm 0,75 \mathrm{~dB}$ & $38,12 \pm 0,78 \mathrm{bC}$ & $7,64 \pm 1,12 \mathrm{cA}$ & $13,86 \pm 1,17 \mathrm{cB}$ & $7,91 \pm 1,68 \mathrm{dA}$ \\
\hline
\end{tabular}

Total Phenolics (mg gallic acid /100g)

Total Flavonoids (mg rutin/100g)

\begin{tabular}{cccc|ccc}
\cline { 2 - 6 } & \multicolumn{1}{c}{ Guava } & Pulp & Guava Paste & Guava & Pulp & Guava Paste \\
\hline Batches 1 & $1069,54 \pm 8,16 \mathrm{abA}$ & $1233,16 \pm 6,12 \mathrm{aB}$ & $682,29 \pm 8,32 \mathrm{aC}$ & $142,17 \pm 1,30 \mathrm{aA}$ & $235,38 \pm 5,62 \mathrm{aB}$ & $125,43 \pm 4,19 \mathrm{aC}$ \\
Batches 2 & $1462,86 \pm 3,92 \mathrm{cA}$ & $1733,91 \pm 9,52 \mathrm{bB}$ & $1008,09 \pm 8,70 \mathrm{bC}$ & $187,41 \pm 0,59 \mathrm{bA}$ & $185,46 \pm 3,78 \mathrm{bA}$ & $171,32 \pm 2,41 \mathrm{bB}$ \\
Batches 3 & $1090,34 \pm 9,96 \mathrm{aA}$ & $1056,53 \pm 16,96 \mathrm{cA}$ & $756,42 \pm 12,47 \mathrm{cB}$ & $125,22 \pm 0,34 \mathrm{cA}$ & $246,84 \pm 0,05 \mathrm{aB}$ & $122,38 \pm 5,90 \mathrm{aA}$ \\
Batches 4 & $1047,55 \pm 3,30 \mathrm{bA}$ & $1032,80 \pm 14,05 \mathrm{cA}$ & $761,57 \pm 9,37 \mathrm{cB}$ & $145,79 \pm 2,69 \mathrm{aA}$ & $260,58 \pm 0,40 \mathrm{cB}$ & $142,45 \pm 4,29 \mathrm{cA}$
\end{tabular}

* In each response variable, the mean values followed by lower case letters in the columns and upper case in the lines do not differ statistically (5\% significance level by Tukey test).

The contents of phenolic compounds in guava and its derivatives have been shown to be relevant in literature. $\mathrm{Fu}$ et al. (2016) verified that guava (in addition to persimmon and pineapple) were the fruits with the highest content of phenolic compounds and in guava, catechin and quercetin were the most expressive quantitatively. Sousa et al. (2011a) found that acerola and guava had the highest concentration of total phenolics when compared to other tropical fruits (such as pineapple, bacuri, cupuaçu and graviola). An interest in quantifying these compounds even in parts such as guava seeds (HERNÁNDEZ-ACOSTA et al., 2011), and guava leaves (SEO et al., 2014; ZAHIN et al., 2016) and other by-products (ARAÚJO et al., 2014) was also observed, aiming at their use as input in other industries. Zahin et al. (2016) reported that guava is a promising fruit to be exploited, due to its high amount of phenolic compounds, which according to the authors, would be responsible for a large part of the antioxidant properties of guava.
Antioxidant capacity (antiradical DPPH•activity)

Guava has been highlighted in literature due to its expressive antioxidant capacity (AMIN and MUKHRIZAH, 2006; MELO et al., 2008; FU et al., 2011; 2016; SOUSA et al., 2011a; 2011b; VIEIRA et al., 2011). $\mathrm{Fu}$ et al. (2011) evaluated the antioxidant capacity of 62 fruits and highlighted guava, among other fruits (FU et al., 2011; 2016). The present study showed an average increase in the antiradical $\mathrm{DPPH} \bullet$ activity in guava pulp of $15 \%$ when compared to fresh guava. In the guava paste, there was a $25 \%$ decrease in the antiradical DPPH • activity in relation to fresh fruit (data not shown).

The mean percentage of antiradical DPPH• activity found in this study for guava 'Paluma' cv. was $78 \%$ in ethanolic extract, a value very close to that found by Melo et al. (2008), where the antioxidant capacity (DPPH method) of the guava acetone extract was higher than $70 \%$. According to Amin and Mukhrizah (2006), red guava had the highest antioxidant activity compared to other extracts (cocoa shell, gooseberry seed, mango and okara - soy milk residue): $68 \%$ (in methanolic extract). In a study carried out with wet residues of fruit pulps (pineapple, acerola, 
bacuri, cupuaçu, bacuri, guava and graviola), Sousa et al. (2011b), verified that the hydroalcoholic extract of guava residue had the highest antioxidant activity (evaluated by the DPPH method). Vieira et al. (2011) reported that the in vitro antioxidant activity of the aqueous and hydroalcoholic extracts of acerola, cashew and guava pulps were the most significant when compared to the other fruits analyzed in the study.

Importantly, the antioxidant capacity of a fruit is closely related to the amount, chemical structure and activity of its bioactive compounds. Since the quantification of bioactive compounds is dependent on their extraction, some factors may affect this step (such as solvents used in extraction, solubility, extraction time, temperature, $\mathrm{pH}$, proportion in the matrix), influencing the extraction of bioactive compounds and consequently the antioxidant capacity of a fruit (or any compound). Thus, there is no gold standard of universal extraction, making it advantageous to use different methods to determine the antioxidant activity of a fruit (DUZZIONI et al., 2010; FREIRE et al., 2013).

In this study, the antiradical DPPH• activity of guava 'Paluma' cv. was compared to standards of ascorbic acid, gallic acid, rutin, BHT (butylhydroxytoluene), lycopene and $\beta$-carotene at $50 \mathrm{mM}$ concentration (Figure 1). Kim et al. (2002) found the same descending order of classification for the antioxidant capacity of the above standards: gallic acid $\geq$ ascorbic acid $>$ rutin $>$ BHT. Brand-Williams et al. (1995) classified the efficiency of antiradicals according to the reaction kinetics, and among those defined as standards in this study; ascorbic acid is classified as fast and gallic acid and BHT, classified as slow.

It could be observed that standards ascorbic acid, gallic acid, rutin and BHT showed excellent scavenging activity of the DPPH radical, all above 93\% (Figure 1). For the analyzed carotenoids (lycopene and $\beta$-carotene), antiradical DPPH $\bullet$ activity was observed, since they were able to react with the radical to scavenge $\mathrm{DPPH} \cdot$, even with the use of a 40 -fold lower aliquot than the others (the reduction in the concentration of the aliquot of these compounds was necessary due to their intense coloration). Comparing carotenoids with each other, $\beta$-carotene is found to have about $49 \%$ less antiradical $\mathrm{DPPH} \bullet$ activity than lycopene (Figure 1); which confirms findings in literature (BÖHM et al., 2002), where lycopene is the most efficient antioxidant among carotenoids.

The correlation between antiradical DPPH • activity of guava and its by-products with each antioxidant compound individually (Table 2) was established. There was a positive correlation between all antioxidant compounds and the antiradical activity, and as a rule of interpretation for the Pearson correlation coefficient, a rule described in literature was used (MUKAKA, 2012). The antiradical $\mathrm{DPPH} \bullet$ activity of guava 'Paluma' cv. showed moderate correlation with the ascorbic acid content (0.6970), very close to the lower limit of the 'strong correlation' interpretation (starting at 0.70 ). In addition, the antiradical activity of guava showed a moderate correlation with total carotenoids ( 0.5643$)$ and total phenolics $(0.5885)$. For guava, an inverse behavior is observed, that is, a negligible correlation $(0.0256)$ between the ascorbic acid content and the antiradical DPPH $\bullet$ activity, since ascorbic acid is thermolabile and easily degraded and/or destroyed by high temperatures, which were used in the guava paste production process (FREIRE et al., 2013; TEIXEIRA et al., 2006) and a very high correlation (0.9412) was observed between total carotenoid contents and the antiradical $\mathrm{DPPH} \bullet$ activity, as well as a strong correlation (0.8258) between total phenolic contents and antiradical DPPH• activity (Table 2 ).

It is verified in literature that the total phenolic content presents strong correlation with the antioxidant activity of fruits and their by-products, responsible for the greater contribution of the antioxidant capacity (ALMEIDA et al., 2011; FU et al., 2011; 2016; VIEIRA et al., 2011; ARAÚJO et al., 2014; SILVA et al., 2016; ZAHIN et al., 2016). For Fu et al. (2011), guava was highlighted (among 62 evaluated fruits) in relation to its antioxidant capacity associated with the content of phenolic compounds. According to Almeida et al. (2011), phenolic compounds are the main contributors of the antioxidant capacity of 11 tropical fruits studied by the authors (guava was not studied), with Pearson correlation coefficient of 0.88 (DPPH method). Even in guava leaf extract, the antioxidant capacity had a strong correlation with the content of phenolic compounds (SEO et al., 2014). The expressive antioxidant capacity of phenolic compounds is justified by their chemical structure, where there is the presence of at least one aromatic ring with hydroxyl group (ARAÚJO et al., 2014). As previously mentioned, the antioxidant capacity of a fruit and its by-products is related to the quality, chemical structure and concentration of bioactive compounds (MELO et al., 2008; DUZZIONI et al., 2010). Thus, the antioxidant capacity of fruits and their by-products is the result of a combination and possible synergistic effect of several bioactive compounds found in fruits (SILVA et al., 2016). 
Table 1 - Mean values ( \pm standard deviation) of ascorbic acid, total carotenoids, total phenolics and total flavonoids (variables) of guava cv. 'Paluma', guava pulp and guava paste, at different year times (four different batches).

\begin{tabular}{|c|c|c|c|c|c|c|}
\hline & \multicolumn{3}{|c|}{ Ascorbic Acid (mg/100g) } & \multicolumn{3}{|c|}{ Total Carotenoids (mg lycopene/100g) } \\
\hline & Guava & Pulp & Guava Paste & Guava & Pulp & Guava Paste \\
\hline Batches 1 & $63,38 \pm 0,01 \mathrm{aA}$ & $76,09 \pm 0,22 \mathrm{aB}$ & $31,48 \pm 0,46 \mathrm{aC}$ & $8,66 \pm 0,70 \mathrm{aA}$ & $11,53 \pm 1,68 \mathrm{aB}$ & $7,23 \pm 1,38 \mathrm{aC}$ \\
\hline Batches 2 & $63,28 \pm 0,99 \mathrm{aA}$ & $80,48 \pm 0,47 \mathrm{bB}$ & $37,00 \pm 0,42 b C$ & $8,57 \pm 1,52 \mathrm{aA}$ & $11,68 \pm 0,34 \mathrm{aB}$ & $5,81 \pm 0,24 \mathrm{bC}$ \\
\hline Batches 3 & $52,36 \pm 0,47 \mathrm{bA}$ & $54,01 \pm 0,89 \mathrm{cA}$ & $29,91 \pm 0,67 \mathrm{aB}$ & $6,64 \pm 0,04 \mathrm{bA}$ & $12,92 \pm 1,10 \mathrm{bB}$ & $6,40 \pm 0,40 \mathrm{cA}$ \\
\hline \multirow[t]{3}{*}{ Batches 4} & $56,09 \pm 0,01 \mathrm{cA}$ & $59,37 \pm 0,75 \mathrm{~dB}$ & $38,12 \pm 0,78 \mathrm{bC}$ & $7,64 \pm 1,12 \mathrm{cA}$ & $13,86 \pm 1,17 \mathrm{cB}$ & $7,91 \pm 1,68 \mathrm{dA}$ \\
\hline & \multicolumn{3}{|c|}{ Total Phenolics (mg gallic acid /100g) } & \multicolumn{3}{|c|}{ Total Flavonoids (mg rutin/100g) } \\
\hline & Guava & Pulp & Guava Paste & Guava & Pulp & Guava Paste \\
\hline Batches 1 & $1069,54 \pm 8,16 \mathrm{abA}$ & $1233,16 \pm 6,12 \mathrm{aB}$ & $682,29 \pm 8,32 \mathrm{aC}$ & $142,17 \pm 1,30 \mathrm{aA}$ & $235,38 \pm 5,62 \mathrm{aB}$ & $125,43 \pm 4,19 \mathrm{aC}$ \\
\hline Batches 2 & $1462,86 \pm 3,92 \mathrm{cA}$ & $1733,91 \pm 9,52 \mathrm{bB}$ & $1008,09 \pm 8,70 \mathrm{bC}$ & $187,41 \pm 0,59 \mathrm{bA}$ & $185,46 \pm 3,78 \mathrm{bA}$ & $171,32 \pm 2,41 \mathrm{bB}$ \\
\hline Batches 3 & $1090,34 \pm 9,96 \mathrm{aA}$ & $1056,53 \pm 16,96 \mathrm{cA}$ & $756,42 \pm 12,47 \mathrm{cB}$ & $125,22 \pm 0,34 \mathrm{cA}$ & $246,84 \pm 0,05 \mathrm{aB}$ & $122,38 \pm 5,90 \mathrm{aA}$ \\
\hline Batches 4 & $1047,55 \pm 3,30 \mathrm{bA}$ & $1032,80 \pm 14,05 \mathrm{cA}$ & $761,57 \pm 9,37 \mathrm{cB}$ & $145,79 \pm 2,69 \mathrm{aA}$ & $260,58 \pm 0,40 \mathrm{cB}$ & $142,45 \pm 4,29 \mathrm{cA}$ \\
\hline
\end{tabular}

Table 2 - Correlation values (Pearson coefficient) between antiradical activity DPPH • (\%) and antioxidant compounds (ascorbic acid, total carotenoids, total phenolics and total flavonoids) of guava cv. 'Paluma', guava pulp and guava paste.

\begin{tabular}{cccc}
\hline & Guava & Pulp & Guava Paste \\
\hline Ascorbic Acid & 0,6970 & 0,3075 & 0,0256 \\
Total Carotenoids & 0,5643 & 0,2229 & 0,9412 \\
Total Phenolics & 0,5885 & 0,1129 & 0,8258 \\
Total Flavonoids & 0,4366 & 0,0294 & 0,5643 \\
\hline
\end{tabular}

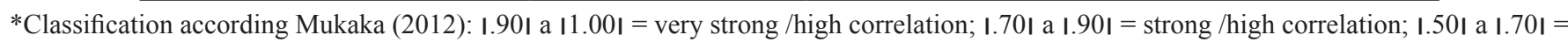
moderate correlation; $\mathrm{I} .30 \mathrm{I}$ a $\mathrm{I} .50 \mathrm{I}=\mathrm{low}$ correlation; $.00 \mathrm{a} \mathrm{I} .30 \mathrm{I}=$ negligible correlation.

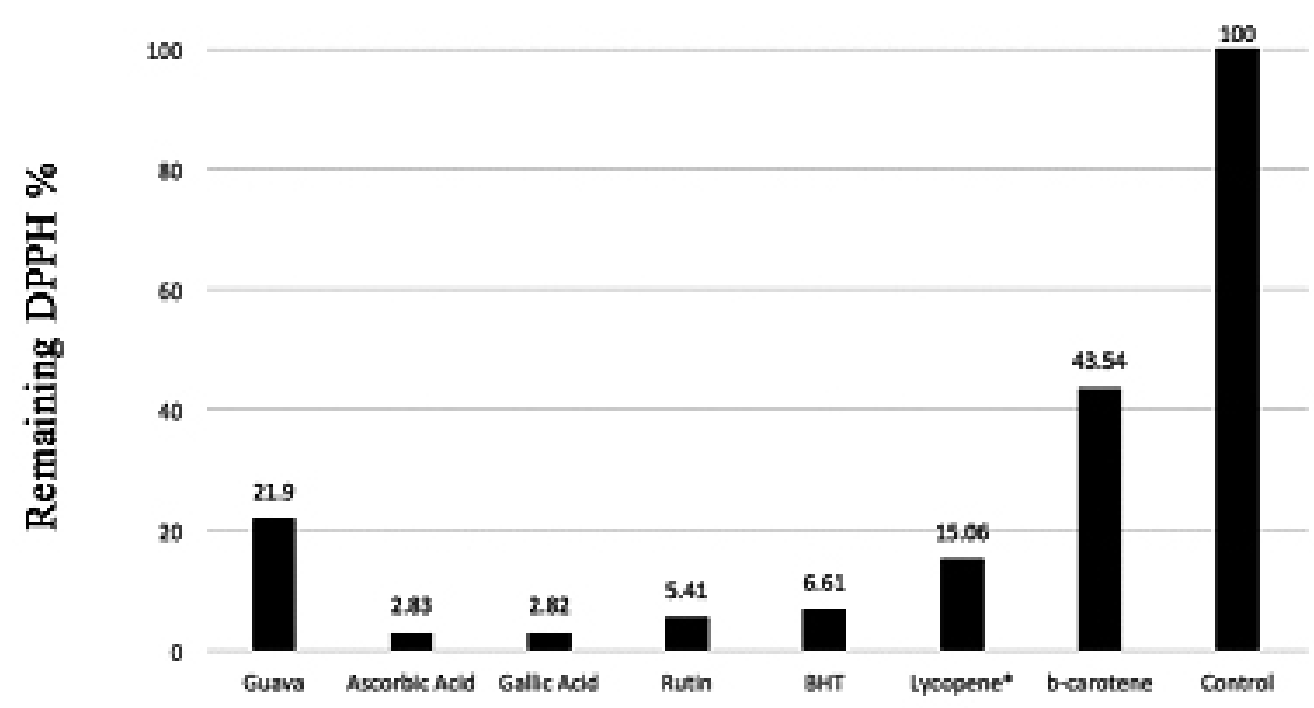

Figure 1 - Comparison between antiradical activity DPPH • of guava samples cv. 'Paluma', from the standards of ascorbic acid, gallic acid, rutin, BHT, lycopene and $\beta$-carotene with the control (without antioxidant substance), expressed as remaining DPPH \%.

*Aliquot 40 times smaller than the others, due to the intense coloration of this compound. 


\section{Conclusion}

It was concluded that guava 'Paluma' cv. and its byproducts are sources of antioxidant compounds and exhibit antiradical DPPH activity that is positively correlated with these compounds. Moderate correlation is verified between the antiradical DPPH• activity of fresh guava and the content of ascorbic acid, total carotenoids and total phenolics; and with the antiradical DPPH • activity of guava, the total carotenoid contents present very strong correlation and the total phenolic contents present a strong correlation.

With industrial processing, the average levels of ascorbic acid, total carotenoids, total phenolics and total flavonoids in guava pulp were increased by $15,59,8$ and $54.5 \%$ respectively, as well as the antiradical DPPH• activity by $15 \%$ in relation to fresh fruit; and reduction of these compounds by $42,13,31$ and $6.5 \%$, respectively, as well as the antiradical $\mathrm{DPPH} \cdot$ activity by $25 \%$; It is therefore concluded that there is an effect of industrial processing on the antioxidant compounds of fresh fruits.

\section{Acknowledgments}

To CAPES for the Master's scholarship for the first author.

\section{References}

ALMEIDA, M.M.B.; SOUSA, P.H.M.; ARRIAGA, A.M.C.; PRADO, G.M.; MAGALHÃES, C.E.C.; MAIA, G.A.; LEMOS, T.L.G. Bioactive compounds and antioxidant activity of fresh exotic fruits from northeastern Brazil. Food Research International, Toronto, v.44, n.7, p.2155-2159, 2011.

AMIN, I.; MUKHRIZAH, O. Antioxidant capacity of methanolic and water extracts prepared from foodprocessing by-products. Journal of the Science of Food and Agriculture, New York, v.86, n.5, p.778-784, 2006.

AMORIM, D.A.; ROZANE, D.E.; SOUZA, H.A.; MODESTO, V.C.; NATALE, W. Adubação nitrogenada e potássica em goiabeiras 'Paluma': Efeito na produtividade e na qualidade dos frutos para industrialização. Revista Brasileira de Fruticultura, Jaboticabal, v.37, n.1, p.201209, 2015.
ARAÚJO, K.L.G.V.; MAGNANI, M.; NASCIMENTO, J.A.; SOUSA, A.L.; EPAMINONDAS, P.S.; SOUZA, A.L.; QUEIROZ, N.; SOUZA, A.G. Antioxidant activity of co-products from guava, mango and barbados cherry produced in the Brazillian Northeast. Molecules, Basiléia, v.19, n.3, p.3110-3119, 2014.

ARAÚJO, H.M.; RODRIGUES, F.F.G.; COSTA, W.D.; NONATO, C.F.A.; RODRIGUES, F.F.G.; BOLIGON, A.A.; ATHAYDE, M.L.; COSTA, J.G.M. Chemical profile and antioxidant capacity verification of Psidium guajava (Myrtaceae) fruits at different stages of maturation. Excli Journal, Dortmund, v.14, p.1020-1030, 2015.

BÖHM, V.; PUSPITASARI-NIENABER, N.L.; FERRZZI, M.G.; SCHWARTZ, J.J. Trolox equivalent antioxidant capacity of different geometrical isomers of $\alpha$-carotene, $\beta$-carotene, lycopene and zeaxanthin. Journal of Agricultural and Food Chemistry, Washington, v.50, n.1, p.221-226, 2002.

BRAND-WILLIAMS, W.; CUVELIER, M.E.; BERSET, C. Use of a free radical method to evaluate antioxidant activity. LWT-Food Science and Techology, Amsterdam, v.28, n.1, p.25-30, 1995.

DUZZIONI, A.G.; FRANCO, A.G.; DUZZIONI M.; SYLOS, C.M. Determinação da atividade antioxidante e de constituintes bioativos em frutas cítricas. Alimentos e Nutrição, Araraquara, v. 21, n.4, p. 643-649, 2010.

ESCOBAR, A.P. Efeito do processo de obtenção de polpa de goiaba e goiabada sobre os teores de licopeno e de beta-caroteno. 2006. 65 f. Dissertação (Mestrado em Análise de Alimentos) - Faculdade de Ciências Farmacêuticas, Universidade Estadual Paulista, Araraquara, 2006.

FLORES, G.; WU, S.B.; NEGRIN, A.; KENNELLY, E.J. Chemical composition and antioxidant activity of seven cultivars of guava (Psidium guajava) fruits. Food Chemistry, Oxford, v.170, p.327-335, 2015.

FREIRE, J.M.; ABREU, C.M.P.; CORRÊA, A.D.; SIMÃO, A.A.; SANTOS, C.M. Avaliação de compostos funcionais e atividade antioxidante em farinhas de polpa de goiabas. Revista Brasileira de Fruticultura, Jaboticabal, v.34, n.3, p.847-852, 2012.

FREIRE, J.M.; ABREU, C.M.P.; ROCHA, D.A.; CORREAA, A.D.; MARQUES, N.R. Quantificação de compostos fenólicos e ácido ascórbico em frutos e polpas congeladas de acerola, caju, goiaba e morango. Ciência Rural, Santa Maria, v.43, n.12, p.2291-2296, 2013. 
FU, L.; XU, B.T.; XU, X.R.; GAN, R.Y.; ZHANG, Y.; XIA, E.Q.; LI, H.B. Antioxidant capacities and total phenolic contents of 62 fruits. Food Chemistry, Oxford, v.129, n.2, p.345-350, 2011.

FU, L.; WENQING, L.; ZHOU, X.M. Phenolic compounds and in vitro antibacterial and antioxidant activities of three tropic fruits: persimmon, guava, and sweetsop. BioMed Research International, New York,, v.2016, 9 p., 2016.

HELRICH, K. C. Official methods of Analysis of the AOAC. Arlington: Association of Official Analytical Chemists, 1990.

HERNÁNDEZ-ACOSTA, M.A.; CASTRO-VARGAS, H.I.; PARADA-ALFONSO, F. Integrated utilization of guava (Psidium guajava L.): Antioxidant activity of phenolic extracts obtained from guava seeds with supercritical CO2-Ethanol. Journal of the Brazilian Chemical Society, Campinas, v.22, n. 12, p. 2383-2390, 2011.

JAWAHEER, B.; GOBURDHUN, D.; RUGGOO, A. Effect of processing and storage of guava into jam and juice on the ascorbic acid content. Plant Foods for Human Nutrition, Heidelberg, v.58, n.3, p.1-12, 2003.

KIM, D.O.; LEE, K.W.; LEE, H.J.; LEE, C.H. Vitamin $\mathrm{C}$ equivalent antioxidant capacity (VCEAC) of phenolic phytochemicals. Journal of Agricultural and Food Chemistry, Washington, v.50, n.13, p.3713-3717, 2002.

MELO, E.A.; MACIEL, M.I.S.; LIMA, V.L.A.G.; NASCIMENTO, R.J. Capacidade antioxidante de frutas. Revista Brasileira de Ciências Farmacêuticas, São Paulo, v.44, n.2, p.193-201, 2008.

MENEZES, C.C.; BORGES, S.V.; CIRILLO, M.A.; FERRUA, F.Q.; OLIVEIRA, L.F.; MESQUITA, K.S. Caracterização física e físico-química de diferentes formulações de doce de goiaba (Psidium guajava L.) da cultivar Pedro Sato. Ciência e Tecnologia de Alimentos, Campinas, v.29, n.3, p.618-625, 2009.

MUKAKA, M.M. Statistics corner: a guide to appropriate use of correlation coefficient in medical research. Malawi Medical Journal, Lilongwe, v.24, n.3, p.69-71, 2012. (1)

NUNES, J.C.; LAGO, M.G.; CASTELO-BRANCO, V.N.; OLIVEIRA, F.R.; TORRES, A.G.; PERRONE, D.; MONTEIRO, M. Effect of drying method on volatile compounds, phenolic profile and antioxidant capacity of guava powders. Food Chemistry, Oxford, v.197, p.881890, 2016.
ORDÓÑEZ-SANTOS, L.E.; VÁZQUEZ-RIASCOS, A. Effect of processing and storage time on the vitamin $C$ and lycopene contents of nectar of pink guava. Archivos Latinoamericanos de Nutricíon, Venezuela, v.60, n.3, p.280-284, 2010.

ORDÓÑEZ-SANTOS, L.E.; PORTILLA, M.A.O.; RODRIGUEZ, D.X.R. Cinética de degradación térmica de vitamina $\mathrm{C}$ en frutos de guajava (Psidium guajava $\mathrm{L}$.). Revista Lasallista de Investigación, Caldas, v.10, n.2, p.44-51, 2013.

ORDÓÑEZ-SANTOS, L.E.;AGUILAR, P.H.; SOLARTE, O.D.R.; JARAMILLO, M.E.A. Concentración de carotenoides totales en resíduos de frutas tropicales. Produción+ Limpia, Caldas, v.9, n.1, p.91-98, 2014.

PINTO, J.T. Efeito da estocagem da goiabada a diferentes temperaturas sobre os teores de carotenoides e de ácido ascórbico. 2006. 80 f. Dissertação (Mestrado em Análise de Alimentos) - Faculdade de Ciências Farmacêuticas, Universidade Estadual Paulista, Araraquara, 2006.

RODRIGUEZ-AMAYA, D.B. A guide to carotenoid analysis in food. Washington: International Life Science Institute (ILSI) Press, 1999. 64p.

SCALBERT, A.; MONTIES, B.; JANIN, G. Tannins in wood: Comparison of different estimation methods. Journal of Agricultural and Food Chemistry, Washington, v.37, n.5, p.1324-1329, 1989.

SEBRAE - Serviço Brasileiro de Apoio às Micro e Pequenas Empresas. O cultivo e o mercado da goiaba. Disponível em: $<$ http://www.sebrae.com.br $><$ http://www. sebrae.com.br/sites/PortalSebrae/artigos/O-cultivo-e-omercado-da-goiaba $>$. Acesso em: 30 mar. 2016.

SEO, J.; LEE, S.; ELAM, M.L.; JOHNSON, S.A.; KANG, J.; ARJMANDI, B.H. Study to find the best extraction solvent for use with guava leaves (Psidium guajava L.) for high antioxidant efficacy. Food Science and Nutrition, New York, v.2, n.2, p.174-180, 2014.

SILVA, N.K.V.; SABINO, L.B.S.; OLIVEIRA, L.S.; TORRES, L.B.V.; SOUSA, P.H.M. Effect of food additives on the antioxidant properties and microbiological quality of red guava juice. Revista Ciência Agronômica, Fortaleza, v.47, n.1, p.77-85, 2016.

SOUSA, M.S.B.; VIEIRA, L.M.; SILVA, M.J.M.; LIMA, A. Caracterização nutricional e compostos antioxidantes em resíduos de polpas de frutas tropicais. Ciência e Agrotecnologia, Lavras, v.35, n.3, p.554-559, 2011 a. 
SOUSA, M.S.B.; VIEIRA, L.M.; LIMA, A. Fenólicos totais e capacidade antioxidante in vitro de resíduos de polpas de frutas tropicais. Brazilian Journal of Food Technology, Campinas, v.14, n.3, p.202-210, 2011 b.

TEIXEIRA, J.; PETRARCA, M.H.; TADIOTTI, A.C.; SYLOS, C.M. Degradação do ácido ascórbico em goiabada industrializada submetida a diferentes condições de estocagem. Alimentos e Nutrição, Araraquara, v.17, n.3, p.281-286, 2006.

TOOR, R.K.; SAVAGE, G.P. Effect of semi-drying on the antioxidant components of tomatoes. Food Chemistry, Oxford, v.94, n.1, p.90-97, 2006.

VICENTE, A.R.; MARTÍNEZ, G.A.; CHAVES, A.R.; CIVELLO, P.M. Effect of heat treatment on strawberry fruit damage and oxidative metabolism during storage. Postharvest Biology and Technology, Amsterdam, v.40, n.2, p.116-122, 2006.
VIEIRA, L.M.; SOUSA, M.S.B.; MANCINI-FILHO, J.; LIMA, A. Fenólicos totais e capacidade antioxidante in vitro de polpas de frutos tropicais. Revista Brasileira de Fruticultura, Jaboticabal, v.33, n.3, p.888-897, 2011.

YU, D.; DAHEGREN, R.A. Evaluation of methods for measuring polyphenol in coniter foliage. Journal of Chemical Ecology, Heidelberg, v.26, n.9, p.2119-2140, 2000.

ZAHIN, M.; AHMAD, I.; AQIL, F. Antioxidant and antimutagenic potential of Psidium guajava leaf extracts. Drug and Chemical Toxicology, London, v.7, p.1-8, 2016.

ZHISHEN, J.; MENGCHENG, T.; JIANMING, W. The determination of flavonoid contents in mulberry and their scavenging effects on superoxide radicals. Food Chemistry, Oxford, v.64, n.4, p.555-559, 1999. 